- анализ структуры построения речевого акта, то есть социальных ролей коммуникантов, их общественный опыт, контекст, а также формирование коммуникативных компетенций;

- овладение техникой речи, знание норм русского литературного языка;

- овладеть навыками выступлений перед камерой, перед микрофоном, использование в своей будущей работе технических средств, компьютерных систем, электронной почты, переговорных устройств.

Таков примерный минимум навыков и умений профессионального речевого общения, которые могут быть сформированы в процессе обучения студентов на занятиях практического курса русского языка. При этом следует отметить, что четко разграничить профессиональные функции речи у будущего инженера невозможно.

Следовательно, формирование речевой компетентности студентов в условиях усложнения информационной и коммуникационной профессиональной среды первостепенная задача, которая должна решаться еще на этапе их учебнопрофессиональной подготовки в вузе [1].

Обобщение полученных результатов исследования и выводы автора статьи раскрывают отдельные аспекты многогранной проблемы формирования речевой компетентности обучающихся и указывают на необходимость ее дальнейшей разработки на основе интеграции практического опыта и теоретического знания из различных областей наук.

$$
* * *
$$

1. Артемьева Г.Н. Формирование речевой компетентности будущих специалистов в области образования на этапе профессиональной подготовки в вузе // Мир науки. Педагогика и психология, 2020 №1, https://mir-nauki.com/PDF/76PDMN120.pdf (доступ свободный)

2. Ахметова Н.А., Таштанкулова Ж.Ж. Использование метода проектов при обучении устному общению на русском языке как неродному // Педагогика и психология: актуальные вопросы теории и практики. 2016. № 3 (8). С. 44-47.

3. Гирич 3. И. Особенности конструирования тестов, ориентированных на тюркоязычную аудиторию // Вісник Дніпропетровського університету імені Альфреда Нобеля. Серія «Педагогіка i психологія». Педагогічні науки, 2014. С. 102-107.

4. Добаев К.Д. Система высшего образования Кыргызстана: переход на двухуровневую систему // Известия Кыргызской академии образования. Бишкек, 2011. № 4. С. 49-52.

5. Касаболотова Г.А. Обучение профессионально ориентированному чтению на русском языке студентов-бакалавров национальных групп языковых факультетов : авторефер. дис. ...канд. пед. наук : 13.00.02. Бишкек, 2017. 23 с.

6. Куттубаева Д.Д. Назначение и объем лексического минимума в обучении лексике студентов национальных групп неязыковых факультетов // Вестник КГУ им. И. Арабаева. Бишкек, 2012. № 1. C. $126-128$.

7. Х Хасанов Н.Б. Практический курс русского языка /учеб. метод. пособие. Бишкек., 2016. - 260 с.

8. Хасанов Н.Б. Изучение темы «Моя специальность» на занятиях русского языка в техническом вузе // Научный мир Казахстана/ - Тараз, 2012. - № 2. - С. 224-228.

9. Ходжиматова Г.М. Научные основы обучения терминологической лексике русского языка в неязыковом вузе : дис. ... д-ра пед. наук : 13.00.02. Душанбе, 2011. 320 с.

\title{
Эхаева P.М. \\ Инновационные формы проведения родительских собраний в образовательных организациях
}

ФГБОУ ВО «Чеченский государственный университет»

(Россия, Грозныгй)

doi: 10.18411/lj-07-2021-159

\section{Аннотация}

Традиционная форма контактов школы и родителей - родительские собрания. Существует тенденция: снижение посещаемости родительских собраний по мере 
взросления детей. Для изменения такой тенденции учителям необходимо применять инновационные формы проведения встреч с родителями.

Ключевые слова: родительские собрания, учитель, инновационные формы.

\section{Abstract}

The traditional form of contact between school and parents is parental meetings. There is a trend: the attendance of parents' meetings decreases as children grow up. To reverse this trend, teachers need to use innovative forms of meeting with parents.

Keywords: parenting meetings, teacher, innovative forms.

Изменение социальной жизни нашего общества влечет инновационные преобразования и в образовательных организациях. Особое внимание школы направлено на установление и упрочнение связей и взаимодействий с семьями обучающимися. Это связано с повышенным вниманием государства и общества к проблемам воспитания подрастающего поколения. Вместе с тем, приходится констатировать самоустранение родителей от проблем школы, класса, самочувствия и положения в нем их ребенка.

Классным руководителям приходятся искать инновационные методы и формы взаимодействия с родителями учеников. В педагогике инновация (от лат. innovatio обновление, ново-в-ведение, изменение) означает применение новых форм, методов и средств, которые приводят к ранее неизвестному результату, обогащая теорию и практику образования [1].

Изменение форм взаимодействия с родителями обучающихся относятся к 4 уровню инноваций - эвристические решения (по А.В. Хуторскому) [2]. Согласимся, что эвристические решения всегда тесно связаны с творческой деятельностью. Отличительной особенностью педагогического творчества является то, что оно всегда связано с человеком. Данное обстоятельство предполагает наличие хорошо развитых рефлексивных умений у учителей, соблюдение ими этических норм и правил взаимодействия [3].

Педагогическое творчество классного руководителя имеет несколько направлений, одно из которых общение и взаимодействие с родителями. Традиционной формой подобного общения является родительское собрание. Они проводились обычно один раз в четверть и представляли собой некое информирование родителей об учёбе и поведении их детей. Многие классные руководители не утруждали себя даже подготовкой к собранию, информацию озвучивали по классному журналу.

Сегодня во всех школах есть электронный дневник и каждый родитель (по желанию ежедневно) может отслеживать успехи или их отсутствие в учебе ребенка. Информационная роль собрания очень сократилась: осталась ли информация о поведении учеников, к которой родители относятся не слишком трепетно.

Вместе с тем у современных школьников достаточно много проблем, поэтому родителям очень нужны советы, консультации, позитивные примеры от педагоговпрофессионалов. Поэтому мы считаем необходимым применять новые формы родительских собраний.

Приведем примеры некоторых из них.

"Душевный разговор" - собрание проводится с группой родителей, дети которых имеют одинаковые проблемы в поведении. Например, рассеянное внимание, опоздание на уроки, невыполнение указаний учителя, агрессивность и т.п. Подобный разговор направлен на установление причины проблемы в поведении и поиск способов и методов ее устранения. Если причины будут относиться к психологическому климату в семье, родительским установкам в воспитании, осложненным детско-родительским отношениям, то дальнейшая работа должна быть только индивидуальна с каждой семьей. 
«Аукцион» - такое собрание представляет собой «продажу» полезных советов по теме собрания в игровой форме. Такое собрание состоит из трех частей. 1 часть учитель кратко объясняет сущность вопроса (например, что такое внимательность), 2-я часть - родители обмениваются опытом своей работы по развитию внимательности у ребенка, предлагают известные им упражнения и игры. Если родители в классе достаточно молоды, то успешно можно использовать игровые элементы. Например, за каждый ответ (совет, пример игры) родитель получает карточку. В конце подводится итог.

Можно повысить состязательность между родителями. В таком случае:

1) карточки могут быть разного цвета, а, следовательно, иметь разные веса баллы);

2) набор баллов может быть не только по результатам собрания, что вполне очевидно. Но и такие баллы активности, умений и педагогических знаний могут накапливаться за весь год.

3) По результатам годовых собраний можно присваивать «почетные звания родителям», причем их должно быть существенное количество. Например: «самый креативный родитель класса», «самый коммуникабельный ...», «самый активный ...», «самый остроумный ...» и т.д. Или могут быть награды в виде званий «Родитель-друг», «Родитель-наставник», «Родитель-советчик», «Родитель-тьютор» и т.д.

«Ток-шоу" - эта форма собрания предусматривает обсуждение выбранной проблемы с различных сторон. Родители, школа, социальный педагог, психолог или иные специалисты в зависимости от избранной темы. Позицию детей может озвучивать классный руководитель (предварительно собрав информацию у учащихся). Происходит совместное обсуждение позиции каждого выступающего и поиск наиболее приемлемого решения.

«Вечер вопросов и ответов» - это открытое обращение с любым интересующим родителей вопросов к присутствующим учителям и специалистам. Для исключения непредвиденных ситуаций и более качественной подготовки специалистов рекомендуется провести до собрания анкетирования родителей.

«Мастер-класс» - это собрание родителей, на котором каждый имеет право рассказать и показать свои успехи в воспитании ребенка. Как правило, к такому сообщению родители должны подготовиться, поэтому рекомендуется провести предварительную работу с ними. На подготовительном этапе проводится беседа с родителями, разъясняется им тема собрания и выражается просьба: поделиться своим опытом в данном вопросе.

Предложенный опыт можно представить в виде краткого сообщения и разместить в «педагогической копилке», которую мы рекомендуем создать на какой-то виртуальной платформе группу класса (ВКонтакте, Одноклассники и др.).

«Мозговой штурм» - применяется при необходимости совместного решения некой проблемы, имеющейся в классе (группе, школе и т.п.). Этот метод дает хорошие результаты, если все участники объединены одной целью и позитивно настроены на её достижение.

«Мнение каждого родителя» - учитель информирует родителей о проблеме и просит каждого написать кратко свой вариант ёё решения. Фамилии на листах можно не писать. Далее все варианты размещаются на доске и озвучиваются, при этом устанавливается правило: критиковать любой из вариантов ЗАПРЕЩЕНО. Далее в совместном обсуждении осуществляется поиск наиболее эффективных решений для проблемы обсуждения.

«Эвристические вопросы». Это традиционная схема уточняющих вопросов при изучении какой-либо проблемы: Кто? Что? Где? Как? Чем? Когда? Почему? Но последовательность вопросов можно менять, что повлечет за собой и смену смыслов 
вопросов. Данное обстоятельство обусловит новые ракурсы в рассмотрении сложного вопроса. Для изменения традиционной схемы можно приготовить заранее 2-3 набора карточек с вопросами. При обсуждении родители выбирают карточку (не видя ее вопроса) и затем отвечают на него, продолжая мысль предыдущего выступающего. Всего может получиться 21 комбинация вопросов.

Таким образом, применение разнообразных форм проведения родительских собраний будет способствовать:

- повышению интереса родителей к педагогическим вопросам;

- привлечению внимания к проблемам школы и класса;

- росту размышлений о правильности своих поступков в отношении детей;

- возрастание заинтересованности в дискуссиях;

- развитию умений решать сложные ситуации в детско-родительских отношениях.

1. Юсуфбекова, Р.Н. Общие основы педагогической инноватики. Опыт разра-ботки теории инновационных процессов в образовании / Р.Н. Юсуфбекова. - М.: Педагогическое общество, 1991. - $91 \mathrm{c}$.

2. Х Хуторской, А.В. Педагогическая инноватика / А.В. Хуторской. - М.: Ака-демия, 2010. - С. 28-29.

3. Гавриловец, К.В. Гуманистическое воспитание в школе: пособие для ди-ректоров школ, учителей, кл. рук./ К.В. Гавриловец. - Минск: Полымя, 2000. - 128 с.

\section{Chemerilova I.A. \\ Psychological and pedagogical difficulties of parents raising children with disabilities in terms of inclusive practice}

Chuvash state University named I. N. Ulyanov (Russia, Cheboksary)

doi: $10.18411 / \mathrm{lj}-07-2021-160$

\section{Abstract}

The paper presents experimental survey of parents of children with disabilities.

The aim of this study was to identify psychological and pedagogical difficulties of parents of children with disabilities in terms of inclusive practices. Implementation of research tasks was achieved on the basis of methods of psychological diagnostics. The study showed that parents raising children with disabilities face many psychological and pedagogical difficulties. These difficulties hinder the development of parental competencies that are necessary for full child's involvement in an inclusive process.

Keywords: inclusive practice, family support, psychological and pedagogical difficulties of parents, children with disabilities.

\section{Аннотация}

В работе представлены экспериментальные данные обследования родителей, воспитывающих детей с ограниченными возможностями здоровья.

Целью данного исследования стало выявление психолого-педагогических затруднений родителей, воспитывающих детей с ограниченными возможностями здоровья, в условиях инклюзивной практики. Реализация исследовательских задач была достигнута на основе методов психологической диагностики. Исследование показало, что родители, воспитывающие детей с ограниченными возможностями здоровья, сталкиваются с рядом психолого-педагогических затруднений, сдерживающих 